In Greenland, also, the bees are Bombus. Peary saw one quite at the northern end of that country. The one exception in America to the rule that only Bombus occupies the far north, so far as I remember, is the occurrence of Osmia bucephala at Great Slave Lake. In Europe and Siberia the same rule seems to hold, but doubtless several genera go further north than in America. Andrena lapponica, for example, is a decidedly northern type. The object of this note is to draw attention to the interesting question of the northern distribution of bees Those who have occasion to visit northern regions should collect what bees they can, noting the flowers they frequent, and in this way much valuable information may be gained. Probably some of your readers are already in a position to throw light upon the subject.

T. D. A. Cockereil.

Mesilla Park, New Mexico, U.S.A., Nov. 6.

\section{Why Birds are not Killed by Eating Poisonous Fruit.}

THERE is a great difference of opinion on this subject. While some maintain that birds do not eat fruits of this kind, others hold that they eat only the surrounding pulp, as of the berries of Taxus, which is perfectly harmless, whereas the seed is very poisonous; others, again, have maintained that they do not eat sufficient to be poisonous. The real fact is, I believe, that none of these statements are true, but that actually the birds eat largely of these berries, both pulp and seed, and that they very shortly afterwards eject the seeds and skins by the mouth, thus avoiding any poisonous action.

The first experience I had of this habit was in finding in September last an immense number of thrushes and misselthrushes feeding on the berries of Pyrus aucuparia in Sutton Coldfield Park. At least a square mile of ground had every patch of grass covered with the ejected seeds and skins of these berries, all the pulp having disappeared, while the colour of the skins was as bright and fresh as when they were swallowed; showing that they could not have passed through the alimentary canal. Each of the pellets was flat and round, and about the size of a sixpence. The birds were incessantly flying to and fro betwixt the trees in the adjoining woods and the park. The excessive drought of last summer, by decreasing the supply of their ordinary food, was evidently the cause of their attacking the berries at this early period.

The next evidence I had of this being the explanation of their immunity from the effect of poisonous food was in October last when I found on Boxhill, in company with Prof. Conwentz, of Dantzic, a number of similar pellets, but consisting entirely of the seeds and skins of yew berries; the former being as bright green, and the latter as scarlet as they were on the tree. In each of these pellets I counted twenty or more seeds.

The real difficulty in accepting this explanation is that, so far as I know, no one has actually seen the birds eject the seeds. Two friends of mine saw, the other day, what was very nearly the accomplishment of the process. A thrush was seated under a well fruited yew, and going through violent spasmodic contortions, the wings drooping on the ground; they thought it was ill, but it flew away strongly as if there was nothing the matter.

The idea that these birds only suck off the pulp from the berries is, I think, fallacious. Prof. Conwentz and I found under a large tree on Boxhill a great number of smali fruitbearing shoots, which had clearly been bitten off by squirrels; the ground was quite covered with seeds divested of their aril, and unbitten, though a few berries with the pulp bitten had been dropped by the squirrels. Mr. Morton Middleton tells me that at Dicksgrove, Co. Kerry, the yew-berries are largely eaten by thrushes, missel-thrushes, blackbirds, greenfinches, linnets, \&c., and afterwards rejected, but he has not seen the birds in the act of doing this. He says, however, that turkeys, not being able to eject the seeds, are killed by them, although Rhind ("Vegetable Kingdom") says that these, as well as peacocks and fowls, eat them with impunity. Mr. Bennett (NATURE, October I3, I 898) asks for information as to the effect of birds and animals eating poisonous plants, and says that blackbirds eat the berries of Atropa belladonna. It cloes not appear that this was more than a supposition, neither is there any observation, so far as I am aware, as to what part of the berry, seeds or pulp, is poisonous. He says that mice eat the seeds of Datura stramonium. Here again we do not know whether they eat more than the kernel, which they would readily extract from the seed, as I have found them do in the case of
Ranunculus repens, a small hole being bitten at the edge of the seed, while every kernel was extracted from the double-handfuls of seeds, which were collected in heaps.

"J. C." (NATURE, vol. Iviii. p. 597, October 20, I898) saw thrushes feeding freely on the berries of Daphne mezereon, an undoubtedly poisonous plant. In this instance there can be little question that they eject the seeds. He says they were so stupefied that they might apparently have been taken with the hand.

Mr. E. Langley, in the same number of NATURE, says that he saw blackbirds also eat these berries, but they did not appear the worse for a number of them.

Gilbert White ("History of Selborne, I789, 329) speaks of milch-sows being killed by yew-berries, while "barrow-hogs and young sows" did not suffer. He attributes this result to the former being weak and hungry, and therefore eating a much larger quantity.

Prof. Tuson found (Field, 1877) that pheasants were killed by the leaves of yew, and there are several similar instances recorded since that date.

A. von Kerner made a number of experiments to show that seeds eaten by blackbirds, germinated in the following June whilst those not so eaten, remained on the ground three or four years. O. Kirchner says that a species of Motacilla eats the berries; but this I regard as a doubtful statement. I have frequently seen them capture flies attracted by the fruit, but have never seen them touch the fruit itself. Every one is, of course, familar with the manner in which owls disgorge the fur and bones of mice and skulls of small birds, a habit which Mr. Harting tells me is shared by all the raptorial birds, as well as by shrikes, flycatchers, and rooks; and there are other facts alluded to by Sir Herbert Maxwell in his "Memories of the Months," and others of insects feeding on deadly poisons without any injury. The habit of ejecting the indigestible parts of their food by birds, seems to require further observation and experiment.

JOHN LOWE.

\section{Sun-spots and Air Temperature.}

THE following comparison is, I think, instructive :-

Make out' a table (from Greenwich data), in which each month since the beginning of 1841 is simply characterised as + or-, according as its mean temperature has been above the average (warm), or below it (cold).

Then, in each five-year group having a sun-spot maximum year central, count the warm and the cold months; and the same with five-year groups having a minimum central. We get these tables:-

\begin{tabular}{|c|c|c|c|c|c|c|c|}
\hline \multirow{6}{*}{$\begin{array}{l}\text { Max. } \\
\text { groups. } \\
1846-50 \\
1858-62 \\
1868-72 \\
1882-86 \\
1892-96\end{array}$} & & \multicolumn{2}{|c|}{$\begin{array}{c}a \\
\text { Warm } \\
\text { months. }\end{array}$} & \multicolumn{3}{|c|}{$\begin{array}{c}\text { b } \\
\text { Cold } \\
\text { months. }\end{array}$} & $a-b$ \\
\hline & $\ldots$ & $\ldots$ & $3^{8}$ & $\ldots$ & 22 & $\ldots$ & +16 \\
\hline & $\ldots$ & $\ldots$ & $3^{2}$ & $\ldots$ & 28 & $\ldots$ & +4 \\
\hline & $\ldots$ & $\ldots$ & 34 & $\ldots$ & 26 & $\ldots$ & +8 \\
\hline & $\ldots$ & $\ldots$ & 33 & $\ldots$ & 27 & $\ldots$ & +6 \\
\hline & $\ldots$ & $\ldots$ & 35 & $\cdots$ & 25 & $\cdots$ & +10 \\
\hline & & & I 72 & & 128 & & +44 \\
\hline $\begin{array}{l}\text { Min. } \\
\text { groups. }\end{array}$ & & & $\begin{array}{c}a \\
\text { Warm } \\
\text { months. }\end{array}$ & & $\begin{array}{c}b \\
\text { Cold } \\
\text { months }\end{array}$ & & \\
\hline I $84 \mathrm{I}-45$ & $\cdots$ & $\ldots$ & 26 & $\ldots$ & 34 & $\ldots$ & - \\
\hline 185 & $\ldots$ & $\ldots$ & 30 & $\ldots$ & 30 & $\ldots$ & \\
\hline $1865-69$ & $\ldots$ & $\ldots$ & 35 & $\ldots$ & 25 & $\ldots$ & + Io \\
\hline I $877-8 \mathrm{I}$ & $\ldots$ & $\cdots$ & 26 & $\cdots$ & 34 & $\cdots$ & -8 \\
\hline I $888-92$ & $\ldots$ & $\cdots$ & I7 & $\ldots$ & 43 & $\cdots$ & -26 \\
\hline & & & I34 & & 166 & & \\
\hline
\end{tabular}

Thus, in each of the maximum groups, there is an excess of warm months; and taking the whole, an excess of 44 warn months. In most of the minimum groups, on the other hand, an excess of cold months; total excess, 32 months.

With regard to the exceptional case-1865-69-in the second table, it may be worth remarking that $1860-70$ is one of Britckner's warm periods. It seems to me that a consideration of both those cycles-the sun-spot cycle of about i I years, and Brïckner's of about 35 years-furnishes the clue to a great deal of our weather.
A. B. M. NO. I 5 I 7 , VOL. 59] 